that administering very large doses of vitamin to well-nourished people does not have the same effect.

It is sometimes said that the colds produced at this unit are not comparable to those which occur in people who are exposed to natural infection and who may develop hypothetical secondary bacterial infections. We, on the other hand, are impressed with the fact that the colds observed here experimentally are very similar clinically to those, caused by the same viruses, which are observed in clinical practice (Tyrrell, 1965), and we should be surprised if ascorbic acid had any prophylactic or therapeutic value for well-nourished subjects who caught colds at home or at work.

\section{Summary}

Preliminary experiments showed no evidence that ascorbic acid protected cultures against several respiratory viruses or white mice against influenza. In further experiments 91 volunteers were given either $3 \mathrm{~g}$. of ascorbic acid daily or placebo tablets. Three days after the treatment began they received intranasal drops containing an $\mathrm{M}$ rhinovirus, an $\mathrm{H}$ rhinovirus, a "new" rhinovirus which grows only in organ cultures, influenza virus type $\mathrm{B}$, or a "new" virus related to avian bronchitis. The number, duration, and severity of the resulting colds were the same in the treated and control groups. There was no evidence that colds produced by any single virus were favourably affected.

We wish to thank Miss E. M. Bullock and Dr. B. M. Tyrrell for help with the clinical observations, and Miss P. M. Ball for technical assistance. We would also thank Dr. D. Scott, of Roche Products, for helpful discussions and for arranging a generous supply of tablets of vitamin and placebo mixtures.

\section{REFERENCES}

Albanese, M., Bynoe, M. L., and Tyrrell, D. A. J. (1966). Arch. ges. Virusforsch., 18, 356.

Almeida, J., and Tyrrell, D. A. J. (1967). F. gen. Virol. In press.

Banks, H. S. (1964). F. Col. gen. Practit., 8, 371.

- (1965). Lancet, 2, 790.

Barnes, F. E. (1961), N.C. med. 7., 22, 22.

Bartley, W., Krebs, H. A., and O'Brien, J. R. P. (1953). Spec. Rep. Ser. med. Res. Coun. (Lond.), No. 280.

Diehl, H. S., Baker, A. B., and Cowan, D. W. (1938). F. Amer. med. Ass., 11i, 1168 .

Glazebrook, A. J., and Thomson, S. (1942). 7. Hyg. (Lond.), 42, 1.

Horsfall, F. L., jun. (1939). F. exp. Med., 70, 209.

Macon, W. L., (1956). Industr. Med. Surg., 25, 525.

Mallucci, L., and Allison, A. C. (1965). 7. exp. Med., 121, 477.

Ritzel, G. (1961). Helv. med. Act, 28, 63 .

Tebrock, H. E., Arminio, J. J., and Johnston, J. H. (1956). F. Amer. med. Ass., 162, 1227.

Tyrrell, D. A. J. (1965). Common Colds and Related Diseases. London.

\title{
Hazard of Peritoneal Dialysis: Contaminated Fluid
}

\author{
W. K. STEWART,* M.B., M.R.C.P., M.R.C.P.ED. ; D. C. ANDERSON, $\dagger$ M.B., M.R.C.P., M.R.C.P.ED. \\ MARGARET I. WILSON, $¥$ M.SC.
}

Brit. med. F., 1967, 1, 606-607

Peritoneal dialysis has become widely used, largely on account of simplicity and safety. The method became popular only after commercially prepared sterile dialysate and cannulae became available. Recent experience in Dundee has brought to light a potential hazard which merits attention. For the past two years we have used commercially prepared dialysate, supplied in 1-litre plastic containers. The inner bag containing the dialysate is itself enclosed in a thin plastic envelope. The space between the inner bag and the envelope is not sterile. During the past 18 months seven bags with small leaks at the neck have been found. In all seven an obvious mass of fungus was growing in the fluid of the inner bag (see Fig.). Five of these contaminated bags were discovered in the past five months, during which time about 3,000 litres of fluid have been used. These findings led us to examine carefully our current stock of fluid, most of which had been delivered in the immediately preceding two weeks. All containers were inspected against a bright light.

\section{Results}

Of 940 1-litre containers $19(2 \%)$ were clearly defective. One bag and envelope had collapsed completely and it was not investigated further. The remaining 18 had obvious leakage into the space between envelope and bag. The trapped fluid varied in volume from 3 to $540 \mathrm{ml}$., and was cloudy or contained mycelium on inspection. Of the 18 containers $12 \mathrm{had}$

\footnotetext{
- Senior Lecturer, Department of Medicine, Queen's College, and Artificial Kidney Unit, Maryfield Hospital, Dundee.

t Registrar. Medical Professorial Unit and Artificial Kidney Unit, Maryfield Hospital, Dundee.

₹ Lecturer, Department of Bacteriology, Queen's College, Dundee.
}

a mycelial mass varying from white to dark brown within the inner bag, and organisms were cultured from all of these. In the remaining six the fluid of the inner bag appeared clear but organisms were nevertheless cultured from two of them. Four were sterile. The organisms cultured from the inner bags, which might therefore have been introduced into the peritoneum if the existence of contamination had been missed, are listed in Table I. With only cursory inspection at the bedside at least three of these containers might easily have been passed as satisfactory. Also included in Table $I$ are the results of the cultures taken from the seven contaminated bags discovered before the survey of dialysis fluid stocks. Similar

TABLE I - Organisms Isolated by Cultures Taken from Dialysate Within TABLE I.-Organisms Isolated by Cultures
Inner Bag of Grossly Leaking Containers*

types of organisms were grown from the fluid which had leaked and was trapped by the outer envelope of these containers. Judging by the serial numbers, the 25 containers described in Table I were derived from 11 different batches.

The 940 litres of dialysate included 540 litres of low glucose content and 400 litres of high glucose content. Gross leakage 
and contamination was almost three times more frequent with the high-glucose fluid (Table II). This may reflect observed differences in the construction of the necks of the plastic bags, or the fact that, judging by the serial numbers, the bags of high glucose content were on the whole older. In no case, however,

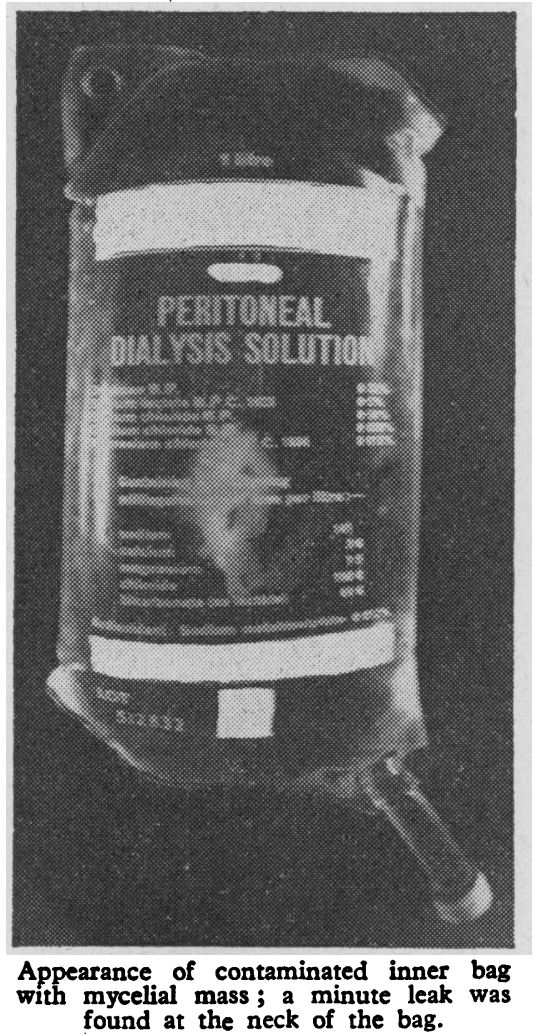

had the manufacturers' recommended expiry date been reached. The cardboard boxes in which the plastic dialysis-fluid bags were packed appeared undamaged.

\begin{tabular}{|c|c|c|c|c|c|c|c|c|c|c|}
\hline \multirow{2}{*}{$\begin{array}{l}\text { Dialys- } \\
\text { sate }\end{array}$} & \multirow{2}{*}{$\begin{array}{l}\text { No. of } \\
\text { Con- } \\
\text { tainers }\end{array}$} & \multicolumn{2}{|c|}{$\begin{array}{c}\text { Gross } \\
\text { Leakage }\end{array}$} & \multicolumn{5}{|c|}{ Moisture Haze } & \multicolumn{2}{|c|}{ Sum } \\
\hline & & Total & $\%$ & Slight & $\begin{array}{c}\text { Moder- } \\
\text { ate }\end{array}$ & Marked & Total & $\%$ & Total & $\%$ \\
\hline $\begin{array}{l}\text { Low } \\
\text { glucose }\end{array}$ & 540 & 6 & $1 \cdot 1$ & 10 & 18 & 5 & 33 & $6 \cdot 1$ & 39 & $7 \cdot 2$ \\
\hline glucose & 400 & 13 & $3 \cdot 3$ & 55 & 9 & 5 & 69 & $17 \cdot 2$ & 82 & 20.5 \\
\hline
\end{tabular}

The remaining 921 of the 940 containers (excluding the 19 with gross leakage) were also carefully inspected. Moisture, in some cases barely visible, was found on the inner surface of some of the outer bags, but was never in sufficient quantity to drain off and measure volumetrically. We found that the incidence of moisture inside the outer envelope was almost three times greater in those of high glucose content. This surface haze or film of fluid occurred in 102 of the 921 containers, and was positive for glucose (Uristix) in all six which were tested. Thirty-six of the 102, including 9 of high and 27 of low glucose content, were tested by culture, and in 31 the trapped moisture yielded air contaminants similar to those shown in Table I. In five the cultures were negative. The dialysate fluid in the inner bag was sterile in all but one instance, in which a pure culture of a Gram-negative bacillus was obtained. It has been noted that the appearance of surface fluid, presumably condensation, could be induced in a dry container by cooling it in a refrigerator. Furthermore, even distilled water becomes glucose-positive to Uristix when rubbed on the outer surface of the inner bag, presumably from unavoidable contamination during filling. It would appear that moisture can result from either condensation or leakage. It is not possible to say which is the case when no obvious leak is seen after squeezing the bag.

\section{Discussion}

The commercial product in question has been available clinically for more than two years, and it is curious that contamination has not been reported earlier. Almost all of the 940 litres examined had been in the hospital store for not more than two weeks, but even in that short time the relatively high storage temperature there (between 67 and $76^{\circ} \mathrm{F}$.; 19.5 and $24.5^{\circ} \mathrm{C}$.) may have accounted for the luxuriant growth of moulds, which otherwise might have remained inconspicuous.

It is true that culture of even the grossly contaminated fluid yielded generally non-pathogenic organisms. However, three cases of infection by the usually saprophytic organism Serratia marcescens have been described during peritoneal dialysis (McCracken and Lipscomb, 1965). Furthermore, in many centres patients with recent abdominal wounds, and patients who are receiving steroids, antibiotics, or immunosuppressive drugs are treated with peritoneal dialysis, and in these cases some of the air contaminants may be less innocuous than usual.

We have found that Aspergillus fumigatus, another common air contaminant, grows well at room temperature in this fluid. In Dundee we have seen a fatal case of aspergillosis, with a probable portal of entry through the peritoneum, complicating peritoneal dialysis in a patient treated with steroids and antibiotics. We would emphasize that we have no direct evidence that the dialysis fluid conveyed the aspergillus in this case (Ross, Anderson, Macnaughton, and Stewart, 1967).

Our findings make us seriously question whether plastic containers as at present produced are sufficiently reliable to be safely used for peritoneal dialysis fluid. We suggest that before clinical use every bag should be inspected carefully, preferably twice, by responsible and trained persons on the hospital staff (once in pharmacy and once in ward), and those containers with more than a trace of moisture inside the outer envelope should be rejected as suspect. Guy and Jenkins (1966) have noted mould and coliform contamination in certain intravenous infusion fluids, and have emphasized in that context the need for visual examination of all fluids before they are used. In addition, we recommend that during peritoneal dialysis cultures of the peritoneal wash should be taken approximately every 12 hours, and that Sabouraud's medium should be plated in addition to the routine culture for bacteria, to allow early detection of bacterial and fungal infections.

\section{Summary}

The discovery over 18 months of seven visibly contaminated and leaking bags of a commercial peritoneal dialysis fluid which is supplied in plastic containers prompted a survey of current stocks of this fluid. Of 940 containers examined $18(2 \%)$ were found to be definitely leaking, and in 14 of these culture of fluid from the inner bag yielded growth of a variety of bacteria and fungi. Moisture was discovered inside the outer envelope of a further 102 containers, and the significance of this is discussed. These findings suggest that infusion of contaminated fluid may represent a serious hazard of peritoneal dialysis when fluid supplied in these containers is used.

We wish to thank Professor Sir Ian Hill and Professor J. P. Duguid for their help and encouragement during the preparation of this paper.

\section{REPERENCES}

Guy, J., and Jenkins, E. W. (1966). Pharm. f., 197, 163.

McCracken, A. W., and Lipscomb, F. E. (1965). Brit. med. 7., 1, 1536 Ross, D. A., Anderson, D. C., Macnaughton, M. C., and Stewart, W. K (1967). Unpublished. 